\title{
RAPD MARKERS UTILIZATION AND OTHER PARAMETERS IN THE DETERMINATION OF MANGO HYBRIDS GENITORS ${ }^{1}$
}

\author{
MARIA CRISTINA ROCHA CORDEIRO ${ }^{2}$, ALBERTO CARLOS DE QUEIRÓZ PINTO³, \\ VÍCTOR HUGO VARGAS RAMOS ${ }^{4}$, FÁBIO GELAPE FALEIRO ${ }^{5}$, LILIA MARTA SANTOS FRAGA ${ }^{6,2}$
}

\begin{abstract}
Actually mango (Mangifera indica, L.) is considered one of the largest Brazilian fruitbusiness for the export market. Cultivar selection having high fruit quality is a fundamental step to obtain excellent results in this business. A mango breeding program based on intervarietal hybridization may produce new improved cultivars for mango growers. Mango hybrids have been obtained by controlled or open crosses. In the last one, it is important to identify the male parent because it is useful for the genetic cultivar history, thus it is important for planning further improvements. This work presents a parentage test using among others parameters RAPD (Random amplified Polymorphic DNA) markers to estimate the male parent of the selected hybrids in an open cross plot by using five mango cultivars densely planted in a latin square design.
\end{abstract}

Index terms - mango tree, intervarietal crosses, genetic improvement.

\section{UTILIZAÇÃO DE MARCADORES RAPD E OUTROS PARÂMETROS NA DETERMINAÇÃo DE GENITORES EM HÍBRIDOS DE MANGUEIRA}

RESUMO - Atualmente, o cultivo da mangueira (Mangifera indica, L.) é considerado um dos maiores agronegócios frutícolas brasileiros para o mercado externo. A seleção de cultivares com elevada qualidade de frutos é uma etapa fundamental para o sucesso deste negócio. O melhoramento genético da mangueira, baseado em hibridações intervarietais, pode originar cultivares superiores aos padrões disponíveis no mercado, ofertando uma nova alternativa ao produtor. Híbridos de mangueira têm sido obtidos por meio de cruzamentos controlados ou abertos. Neste último, é importante identificar o genitor masculino visando a obter a história genética da cultivar além de ser importante no planejamento do melhoramento subseqüente. Este trabalho apresenta um teste de paternidade, utilizando, entre outros parâmetros, marcadores RAPD (Random Amplified Polymorphic DNA), para estimar o genitor masculino de híbridos selecionados em uma área de cruzamento aberto contendo cinco cultivares de manga plantadas em alta densidade, no delineamento experimental do quadrado latino.

Termos para indexação: mangueira, cruzamentos intervarietais, melhoramento genético.

\section{INTRODUCTION}

Mango (Mangifera indica, L.) is one of the largest Brazilian commodities (Pinto et al., 2002) and its fruitbusiness for the export market is basically concentrated in the São Francisco Valley, State of Pernambuco, Brazil. Tommy Atkins has been the most important cultivar grown in this region which corresponded to 111,181 tons of fruits which generated about US \$ 64.3 millions in 2004 (Brazilian Fruit Yearbook, 2005). In the internal market, mango is highly appreciated by fruit consumers and, it is produced both in the Southeast and Northeast regions. At least ten different cultivars have been grown to supply the internal Brazilian market.

Tommy Atkins is the main cultivar grown for export, although it shows negative characteristics such as susceptibility to mango malformation and physiological fruit disorder. In addition, it has a fair taste which is not well accepted by Brazilian consumers. In order to overcome these problems and to offer new cultivars for the external and internal markets, a mango breeding program has been developed in the Brazilian Savannah region in Embrapa Cerrados during the last 25 years. This breeding program has developed cultivars through intervarietal hybridization using important parents from the USA, South Africa, Mexico, India, Thailand, Australia and Brazil (Pinto, 1995; 2001; Pinto et al., 2004). The hybridization procedure is based on an improved technique which was originally described by Mukherjee et al.(1961), followed by agronomical and physico-chemical evaluations. The Mukherjee's technique improved by Pinto (1995) is an efficient hand pollination procedure but, it is still very timeconsuming and needs well-trained people. Furthermore, this technique produces low hybrid population which creates a problem to generate enough progenies for genetic studies on quality characters.

A collection of five important mango cultivars, all of them being monoembryonic has been established in the experimental mango area of Embrapa Cerrados densely planted in a latin square design (Pinto, 2001). This area was established in order to obtain higher hybrids population and larger progenies to facilitate the genetic studies. The experimental design was supposed to allow better directioned crosses since the nearest plant should offer pollen most easily to the neighbor ones thus, allowing obtaining more selected crosses diminishing the undesirable ones. However, in spite of the advantage, it is still necessary to estimate the male parent in order to control undesirable pollinations due to winds or to different flowering period that may occur.

The objective o this paper is to estimate the male genitor of mango hybrids through a parentage test using among others parameters the RAPD markers.

\section{MATERIAL AND METHODS}

The study was carried out at Embrapa Cerrados in a mango area established at a limed and fertilized soil under a latin square design. Embrapa Cerrados is located in Planaltina (DF) at $15^{\circ} 35^{\prime} 3^{\prime \prime} \mathrm{S}$, $47^{\circ} 42^{\prime} 30^{\prime \prime} \mathrm{W}$ and 1,100 meters above sea level (m.a.s.l.). The climate presents two well defined seasons: a wet and hot one with a temperature range from $25^{\circ} \mathrm{C}$ to $30^{\circ} \mathrm{C}$ and 1.400 to $1.800 \mathrm{~mm}$ of total pluviometric precipitation per year (from September to April) and, the other a dry one with a temperature range from $20^{\circ} \mathrm{C}$ to $23^{\circ} \mathrm{C}$ and $40 \%$ average relative humidity (from May to August).

The hybrid seedlings analyzed in this paper were named M1

\footnotetext{
${ }^{1}$ (Trabalho 011-2006). Recebido: 23-01-2006. Aceito para publicação: 06-07-2006. Trabalho financiado com recursos da Embrapa.

${ }^{2}$ Pesquisadora III da Empresa Brasileira de Pesquisa Agropecuária (Embrapa Cerrados), Rod. BR 020, km 18.CEP73310-970, cristina@cpac.embrapa.br.

${ }^{3}$ Pesquisador III da Empresa Brasileira de Pesquisa Agropecuária (Embrapa), Coordenadoria de Cooperação Internacional (CCI), Parque Estação Biológica s/ núm.. CEP70770-901, alberto.pinto@embrapa.br.

${ }^{4}$ Pesquisador III da Empresa Brasileira de Pesquisa Agropecuária (Embrapa Cerrados), Rod. BR 020, km 18.CEP73310-970.vhugo@ julianemoi.com.br

${ }^{5}$ Pesquisador III da Empresa Brasileira de Pesquisa Agropecuária (Embrapa Cerrados), Rod. BR 020, km 18.CEP73310-970, ffaleiro@ cpac.embrapa.br.

${ }^{6}$ Estagiária da Faculdade JK e bolsista da Empresa Brasileira de Pesquisa Agropecuária (Embrapa Cerrados) Rod. BR 020, km 18.CEP73310970.lilia_marta@yahoo.com.br.
} 
and M2 because these seeds were selected in the Southern position from a Mallika plant located in line 5 (female parent). The nearby cultivars were line 1 Roxa, lines 1 and 5 Alfa and lines 1 and 5 Keitt (Figure 1). M1 and M2 seeds were selected from the fruit set of the pollination of 2003 and were germinated in plastic bags with $40 \mathrm{~cm}$ height $\times 25 \mathrm{~cm}$ width $\times 0.2 \mathrm{~mm}$ thickness with lateral perforations, containing a proportion of wet soil and sand (1:1), kept at an irrigated nursery with $50 \%$ of shade condition .

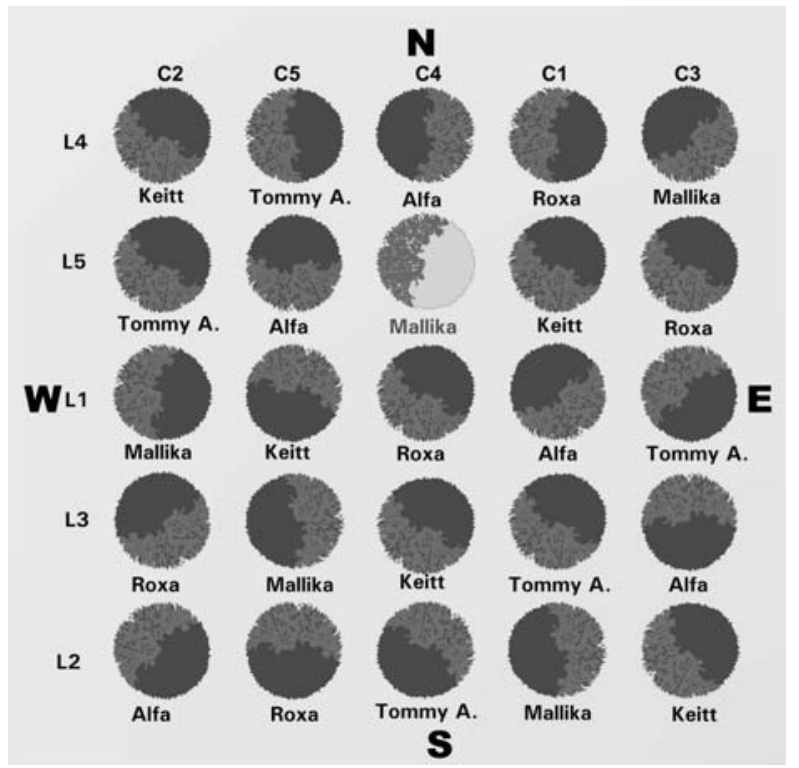

FIGURE 1 - Design of the mango area in latin square. Mallika (female plant) is showed in different colour.

Leaves of the analyzed seedlings (M1 and M2) and the five probable genitors were collected and immediately used to extract the genomic DNA according to Doyle \& Doyle (1990) with some modifications (Faleiro et al., 2003). After the extraction, the purity and concentration of DNA were estimated espectrophotometrically (Sambrook et al., 1989) and DNA samples were diluted to $5 \mathrm{ng} \mu \mathrm{L}^{-1}$. The integrity of the DNA was observed in $0.8 \%$ agarose gels.

DNA samples from each hybrid and parental plants were amplified using RAPD technique described by Welsh \& McClelland (1990) and Williams et al. (1990). Twenty six 10-mer primers (OPD1, OPD2, OPD5, OPD13, OPD18, OPD20, OPE1, OPE5, OPE6, OPE11, OPE15, OPF3, OPF5, OPF7, OPF8, OPG6, OPG12, OPG13, OPG18, OPG19, OPH4, OPH14, OPH15, OPH18, OPH19, OPH20) (Operon Technol.) were utilized to obtain RAPD markers. The amplifications were performed in $\mathrm{MJ}$ Research equipment, programmed to 40 cycles: $15 \mathrm{~s}$ at $94^{\circ} \mathrm{C}, 30 \mathrm{~s}$ at $35^{\circ} \mathrm{C}$ and $90 \mathrm{~s}$ at $72^{\circ} \mathrm{C}$. At the end of the 40 cycles, it was added an extension step of $6 \mathrm{~min}$. at $72^{\circ} \mathrm{C}$. Each amplification reaction contained $15 \mathrm{ng}$ of one DNA, Taq buffer one time concentrated, $3 \mathrm{mM} \mathrm{MgCl}, 100 \mu \mathrm{M}$ dNTP(Amersham), $0.4 \mu \mathrm{m}$ primer (Operon Technol.) and $1 \mathrm{U}$ Taq ploymerase (Invitrogene Inc.). After amplification samples were applied in a $1.2 \%$ agarose gel in TBE (TrisBorato $100 \mathrm{mM}$, EDTA $2 \mathrm{mM}$ ) buffer, which contained ethidium bromide $\left(0.5 \mu \mathrm{g} \mathrm{ml}^{-1}\right)$. The electrophoresis process occurred at $85 \mathrm{~V}$ and lasted about four hours. At the end of the running process, the agarose gels were visualized and photographed (EDAS 120, Kodak) under ultraviolet light (Vilber Lourmat). Each sample was analyzed twice. The reproducible RAPD markers were converted into a matrix of binary data where the presence of the band corresponded to value 1 and the absence to value 0 and, the index of similarity among all plants was estimated based on the coeficient of Ney \& Li (1979) by using the Genes Software (Cruz, 1997). Others parameters, such as plant proximity, flowering season and rate as well as the number of specific fragments amplified between hybrids and the most probable male parent were also used in the discussion. Flowering season and rate were evaluated monthly in the field from May to September during the year 2003. It was considered a scale from zero to three, to have the following flowering rates: $0=10 \%$ bloom; $1=10$ to $25 \% ; 2=25$ to $50 \%$ and $3=50$ to $100 \%$ (full bloom; Figure 2).

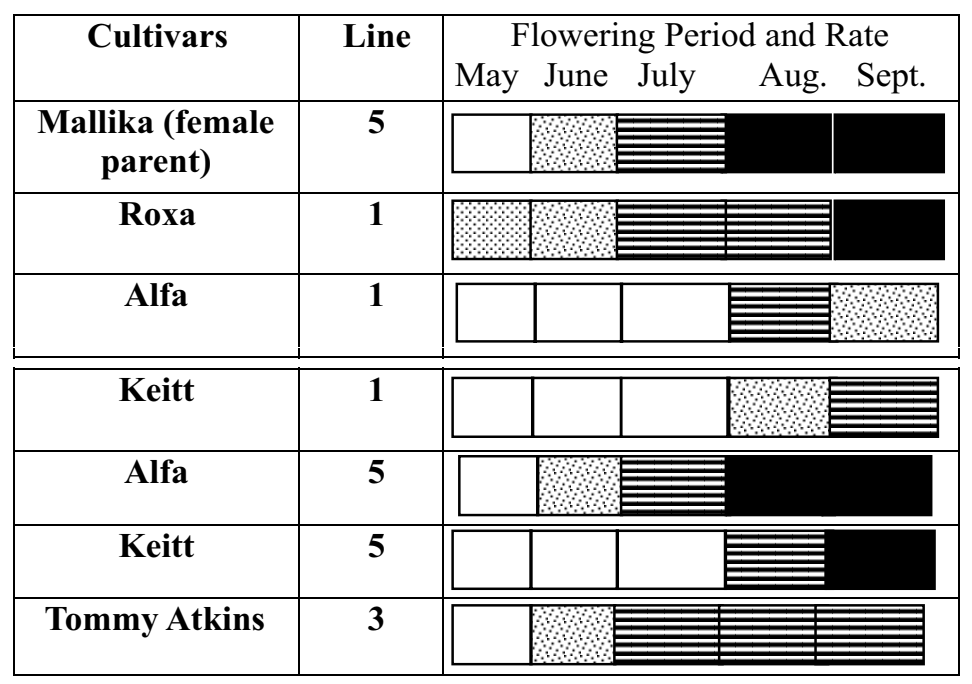

Legend: $=<10 \%$ bloom; $=10$ to $25 \% ;=25$ to $50 \% ;=50$ to $100 \%$ (full bloom) FIGURE 2 - Diagram of flowering rate and season during 2003 year.

\section{RESULTS AND DISCUSSION}

This parentage test based on RAPD was supported by Delaporte et al. (2001) result which showed that this technique was capable to identify the male parent in an inter-specific hybrid of ornamental eucalyptus. This work confirms that RAPD markers are useful for a parentage test as it allows obtaining a similarity index among plants (Table 1) and generates reproducible amplified DNA

TABLE 1 - Index of genetical similarity among parents and hybrids obtained by the similarity coeficient of Nei \& Li (1979) based on the binary matrix of 134 reproducible RAPD bands.

\begin{tabular}{ccc}
\hline Parentals/Hybrids & M1 & M2 \\
Roxa & 0,77 & 0,9 \\
Mallika (female parent) & 0,84 & 0,91 \\
Keitt & 0,75 & 0,77 \\
Alfa & 0,83 & 0,87 \\
Tommy Atkins & 0,83 & 0,88 \\
\hline
\end{tabular}

TABLE 2 - Number of specific DNA fragments amplified between probable male parent and hybrids M1 and M2.

\begin{tabular}{|c|c|c|c|c|c|c|c|c|c|c|c|c|c|c|c|c|c|}
\hline & \multicolumn{17}{|c|}{ SPECIFIC AMPLIFIED DNA FRAGMENTS } \\
\hline $\mathrm{P}$ & 1 & 2 & 3 & 4 & 5 & 6 & 7 & 8 & 9 & 10 & 11 & 12 & 13 & 14 & 15 & 16 & 17 \\
\hline Roxa & 0 & 0 & 0 & 0 & 0 & 1 & 0 & 1 & 1 & 0 & 0 & 1 & 0 & 0 & 1 & 1 & 0 \\
\hline Keitt & 0 & 0 & 0 & 0 & 0 & 0 & 0 & 0 & 0 & 0 & 0 & 0 & 0 & 0 & 0 & 0 & 0 \\
\hline Alfa & 0 & 0 & 1 & 0 & 1 & 0 & 1 & 0 & 0 & 1 & 1 & 0 & 0 & 0 & 0 & 0 & 1 \\
\hline T. A. & 0 & 0 & 0 & 1 & 0 & 0 & 0 & 0 & 0 & 0 & 0 & 0 & 1 & 1 & 0 & 0 & 0 \\
\hline M1 & 1 & 1 & 1 & 0 & 1 & 0 & 0 & 0 & 0 & 1 & 1 & 0 & 1 & 1 & 1 & 1 & 0 \\
\hline M2 & 1 & 1 & 1 & 1 & 1 & 1 & 1 & 1 & 1 & 1 & 1 & 1 & 0 & 0 & 0 & 0 & 0 \\
\hline
\end{tabular}

*Specific amplified fragments code : 1-E6-1; 2-E6-4; 3-E6-6; 4-F7-8; 5-H14-8; 6-H20-14; 7-H20-15; 8-H20-16; 9-F8-7; 10-E15-2; 11-E15-4; 12-E15-11; 13H15-4; 14-H15-10;15-H15-11; 16-H15-18; 17-D18-3. P - Parentals, T.A. - Tommy Atkins variety. 
TABLE 3 - RAPD primers used in the final analysis and the number of respective produced polymorphic and monomorphic bands.

\begin{tabular}{|c|c|c|c|}
\hline Primer & Sequence $\left(5^{\prime} \rightarrow 3^{\prime}\right)$ & Number of polymorphic bands & Number of monomorphic bands \\
\hline OPD-05 & TGAGCGGACA & 8 & 3 \\
\hline OPD-18 & GAGAGCCAAC & 10 & 3 \\
\hline OPE -06 & AAGACCCCTC & 9 & 2 \\
\hline OPE -11 & GAGTCTCAGG & 3 & 4 \\
\hline OPE -15 & ACGCACAACC & 13 & 1 \\
\hline OPF -05 & CCGAATTCCC & 3 & 1 \\
\hline OPF -07 & CCGATATCCC & 6 & 3 \\
\hline OPF -08 & GGGATATCGG & 9 & 0 \\
\hline OPG - 18 & GGCTCATGTG & 4 & 2 \\
\hline OPH - 14 & ACCAGGTTGG & 4 & 4 \\
\hline $\mathrm{OPH}-15$ & AATGGCGCAG & 17 & 2 \\
\hline OPH -19 & CTGACCAGCC & 3 & 4 \\
\hline OPH -20 & GGGAGACATC & 13 & 5 \\
\hline \multicolumn{2}{|c|}{ TOTAL } & 100 & 34 \\
\hline
\end{tabular}

fragments between hybrid and its parents (Table 2).

The index of similarity used in this work was based on 134 total reproducible amplified fragments obtained from thirteen 10-mer primers (OPD5, OPD18, OPE6, OPE11, OPE15, OPF5, OPF7, OPF8, OPG18, OPH14, OPH15, OPH19, and OPH20). Out of 26 10-mer tested primers used, only 50\% gave reproducible results. Out of 134 bands, 100 were polymorphic and 34 were monomorphics (Table 3 ). The mean number of polymorphic amplified fragments was eight fragments per primer and, OPH15 was the primer which presented more polymorphic bands, which shows that the RAPD methodology used in the work is useful. The similarity analysis for the final parentage test, although proven to be useful, seemed to be ambiguous if it is observed alone. Two plants could have the same similarity index as observed in the case of hybrid M1 (Table 1). The reason of this could be that Van Dyke is the male parent of Alfa which is, by its turn, a parentage of Tommy Atkins since both (Tommy and Van Dyke) have Haden as a possible female parent. Keitt was the most divergent cultivar observed in the similarity analysis (Table 1).

Regarding the number of specific amplified DNA fragments the results showed that only eight primers were selected to produce specific fragments between a hybrid and a possible male parent. These primers were OPD18, OPE6, OPE15, OPF7, OPF8, OPH14, OPH15 and OPH20. The primer OPH15 was the one which produced the higher number of specific fragments in a number of four fragments (Table 2). Roxa showed two specific fragments with M1 and four with M2. Alfa showed four specific fragments with M1 and five with M2 and Tommy Atkins two with M1 and only one with M2. Keitt did not show specific fragment between any hybrids. Thus, Keitt is the most improbable male parent (Tables 1 and 2). Despite these positive results, this parameter also causes misinterpretation, if observed alone since it is possible to find a male plant which reproduces more specific DNA fragments related to a hybrid, although it might be less genetically similar to this hybrid. This seemed to be the case of M2 in comparison to Alfa (Tables 1 and 2). For instance, if Roxa is the male parent of M2

TABELA 4 - Final test to estimate probable male parents based on four parameters.

\begin{tabular}{ccccccccc}
\hline & \multicolumn{9}{c}{ Hybrids } \\
P & Alfa & T.A. & Roxa & Keitt & Alfa & T.A. & Roxa & Keitt \\
G. S. & 1 & 1 & 0.5 & 0.25 & 0.75 & 0.75 & 1 & 0.25 \\
P. P. & 0.5 & 0.25 & 1 & 0.5 & 0.5 & 0.25 & 1 & 0.5 \\
F. S. & 1 & 1 & 1 & 0.25 & 1 & 1 & 1 & 0.25 \\
N.S.F & 1 & 0.5 & 0.5 & 0 & 1 & 0.25 & 0.75 & 0 \\
Total & 3.5 & 2.75 & 3.0 & 1.0 & 3.25 & 2.25 & 3.75 & 1.0 \\
\hline
\end{tabular}

scores :1 (high probability); 0.75 (probable); 0.5 (middle probability); 0.25 (low probability. P-parameters, G.S. - genetic smilarity, P.P.-plant proximity, F.S-flowering season, N.S.F-number of specific DNA fragments; T.A.-Tommy Atkins. but Alfa has more specific DNA fragments with it, is easily explained since Roxa and Alfa have genetically related north-american male parents, such as Tommy Atkins and Van Dyke, respectively. Therefore, the results prove that both parameters, index of similarity and specific DNA fragments have to be observed concomitantly.

Plant proximity was selected also as a parameter to estimate the male parent. Up to now, this parameter seems not to be the major reason which influences the pollen effect from the nearby plant since until this moment; plant canopies do not touch each other, although they will certainly have some impact on the directional cross. For example, Tommy Atkins is the most improbable male parent as it is located far from the Southern side of Mallika plant (line 5) or in an opposite direction (Figure 1 and Table 4).

It was observed also that cultivars had different flowering season and rate during the experiment (Figure 2) and, it influences pollination. Keitt was the last to start flowering comparing to the others. It started flowering only in August. Although Keitt from line 5 had coincident bloom rate with Roxa, Mallika and Alfa (line 5) in September, flowering and, consequently, the pollination of these last cultivars might have begun earlier (June).

Alfa (line 1) had also a delayed flowering period which does not develop very well. So, probably, Alfa in line 1 also is not the male parent of any analyzed hybrid.

The flowering rate of Roxa, Mallika and Alfa (line 5) increased in a similar way and in September, their canopies were all almost in full bloom. So, the conducted flowering rate and season observation favours Alfa (line 5) and Roxa (line 1) as male parents. Mallika is the female parent and, the probability of being also the male parent is low due to mango auto-incompatibility.

Better results could be obtained concerning pollen effect if flowering periods were synchronized by using irrigation and flowering induction treatment with paclobutrazol (personal information of Dr. Alberto Carlos de Queiróz Pinto, 2005).

Based on the presented results, the male parents for M1 and M2 are probably Alfa (line 5) and Roxa (line 1) cultivars respectively. According to this result, Roxa (line 1) is the closest plant and, Alfa (line 5) is the nearest to Mallika (line 5) (female parent) which had similar flowering season and rate to it. Moreover, Alfa (line 5) showed a high index of similarity with M1 and Roxa (line 1) with M2. In the case of specific DNA fragments it was observed some discrepancies regarding M2. Because of that, we took the four parameters discussed above in a probability test considering score 1 to demonstrate high probability of occurrence phenomenon ; 0.75 to probable; 0.5 to middle probability and, 0.25 to low probability (Table 4 ) and this test confirm the assumption. Agronomical and physico-chemical evaluations on hybrids can be used to add information to the data obtained here.

The RAPD marker used on this work proved to be useful on this type of study which has a great impact on Mango Genetical Breeding Program and others perennial cultivars. 


\section{CONCLUSIONS}

1 - The RAPD marker is an efficient tool which permits to obtain information on genetic similarity among mango plants and produces specific DNA fragments for a parentage test of hybrids selected in open crosses.

2- The open crosses occurred during 2003 were not due to the closest cultivar since their actual stage of development did not have a full canopy contact.

\section{REFERENCES}

BRASIL. Ministério da Agricultura, Pecuária e Abastecimento. Brazilian FruitYearbook, Brasília, v.1, n.1, p.26, 2005

CRUZ, C.D. Programa Genes: aplicativo computacional em genética e estatística. Viçosa: Ed. UFV, 1997.

DELAPORTE, K.L.; COLLINS, G.G.; CONRAN, J.G.; SEDGLEY, M.. Molecular analysis of an inter-specific hybrid ornamental eucalyptus for parental identification. Euphytica, Netherlands, v.122, n.1,p. 165-170, 2001.

DOYLE, J.J.; DOYLE, J.L. Isolation of plant DNA from fresh tissue. Focus, Moscow, v.12, n.1, p.13-15, 1990.

FALEIRO, F.G.; FALEIRO, A.S.G.; CORDEIRO, M.C.R.; KARIA, C.T. Metodologia para operacionalizar a extração de DNA de espécies nativas do cerrado. Planaltina: Embrapa Cerrados, 2003. v.92, 6p. (Comunicado Técnico, 1)

MUKERJEE, S.K.; MAJUNDER, P.K.; CHATERJEE, S. An improved technique of mango hybridization. Indian Journal of Horticulture, Bangalore, v.18, n.1, p.302-304, 1961.
NEI, M.; LI, W.H. Mathematical model for studying genetic variation in terms of restriction endonucleases. Proceedings of National Academy of Sciences, Allahabad, v. 76, n.1, p.5269-5273, 1979.

PINTO, A.C.Q. Melhoramento da mangueira (Mangifera indica) no ecossistema dos cerrados do Brasil Central por meio da hibridação. Pesquisa Agropecuária Brasasileira., Brasília, v.30, n.1, p.369374, 1995

PINTO, A.C.Q. A Hibridação Intervarietal em Manga (Mangifera indica L.): Técnicas usadas, principais resultados e suas limitações. Revista Brasileira de Fruticultura, Jaboticabal, v. 23, n.1, p. 200-202, 2001

PINTO, A.C.Q; ANDRADE, S.R.M.; AMARO, A.A.; GOMES, U. Mango industry in Brazil. In: INTERNATIONAL MANGO SYMPOSIUM, 7., 2002, Recife, Brasil. Program and Abstracts... fortaleza: EMBRAPA Agroindústria, 2002. p. 41.

PINTO, A.C.Q.; ANDRADE, S.R.M.; RAMOS, V.H.V.; CORDEIRO, M.C.R. Intervarietal hybridization in mango (Mangifera indica L.): techniques, main results and their limitations. Acta Horticulturae, Wageningen, v. 645, n. 1, p.327-330, 2004.

SAMBROOK, J.; FRITSCH, E.F.; MANIATIS, T. Molecular cloning: a laboratory manual. $2^{\text {nd }}$ ed. New York: Cold Spring Harbor Laboratory, 1989.316p.

WELSH, J.; McCLELLAND, M. Fingerprinting genomes using PCR with arbitrary primers. Nucleic Acids Research, Oxford, v. 18, n.1, p.7213-7218, 1990 .

WILLIAMS, J.G.; KUBELIK, A.R.; LIVAK, K.J.; RAFALSKI, J.A.; TINGEY, S.V. DNA polymorphism amplified by arbitrary primers are useful as genetic markers. Nucleic Acids Research, Oxford, , v. 18 , n.1, p. 6531-6535, 1990 . 